\title{
Poliittisen käsitteestä ja kirjallisuudentutkimuksen monimuotoisuudesta
}

Kristina Malmio esitti Avaimessa 2/2007 kysymyksiä ja tarkennuksia postuloimalleen "Hekanahon" hahmolle, josta en tunnista sen paremmin itseäni kirjoittajana kuin esittämiäni käsityksiäkään. Käsitykseni mukaan vapaata ajattelua vainoavan feminatsin muotokuvan taustalla on aiemmassa kirjoituksessani esiintyneen poliittisuus-käsitteen väärinymmärrys, joka yhdistää sekä Malmion ad hominem -argumentointia että kirjallisuuden(tutkimuksen) ja politiikan suhteita kyselevää pääkirjoitusta. Kommentoin seuraavassa lyhyesti Malmion tulkintoja mutta ennen kaikkea keskustelen vallan ja poliittisuuden käsitteistä ja niiden merkityksestä humanistille. Sanoudun myös irti Avaimessa 2/2007 esitetyistä tavoista puhua "poliittisesta" tutkimuksesta, joka poikkeaisi jyrkästi "ei-poliittisesta", ikään kuin aidommin tutkimuksellisesta lähestymistavasta. Nähdäkseni laajemmin ymmärretty poliittisuuden käsite auttaa analysoimaan toimintaamme kattavammin kuin ajatus politiikasta vaaliviikkoihin rajautuvina valintoina tai keskusteluna kirjallisuudentutkimuksen yhteiskunnallisuudesta.

Kun politiikka tulkitaan keskenään kilpaileviksi poliittisiksi agendoiksi, se sijoittuu eri tasolle kuin puhe poliittisuudesta laajemmassa merkityksessä - käsitteenä, joka viittaa esimerkiksi foucault'laiseen vallan analytiikkaan ja ajatukseen siitä, kuinka subjekteina toimimme aina suhteessa tuottavaan ja rajoittavaan valtaan. Väite, että tutkijan jokaisella valinnalla tai vaikenemisella on myös poliittinen ulottuvuutensa, ei siis esitä yhtä politiikan/yhteiskunnallisen toiminnan piiriin kuuluvaa ohjelmaa, johon tutkijoiden tulisi sitoutua tullakseen hyväksytyiksi. Omasta näkökulmastani kysymys, pitääkö kirjallisuudentutkimuksen olla poliittista, on hullunkurinen: koska mikään toimintamme ei tapahdu vallan verkostojen tuolla puolen, kaikki toimintamme on väääämättä yhdeltä ulottuvuudeltaan poliittista. Tätä vallan kaikkialle kirjoittautumista on tapana analysoida esimerkiksi juuri poliittisuuden käsitteen avulla. Kirjallisuuden- ja kulttuurintutkijoille työkaluja ovat tarjonneet esimerkiksi Michel Foucault'n kirjoitukset diskursiivisesta vallasta sekä monet Louis Althusserin ideologiakritiikin edelleenkehittelyt.

Alan Sinfield, arvostettu brittiläinen Shakespeare- ja queer-tutkija, kirjoittaa teoksessaan Cultural Politics - Queer Reading (2007), kuinka jo esimerkiksi käsitys, ettei Shakespearen tuotanto ja tutkimus olisi myös poliittista, on nimenomaan poliittinen ajatus. Niinpä ajatus poliittisuudesta osoittautuu kerran toisensa jälkeen vaikeasti tunnistettavaksi, kun käsitteellä viitataan piilevien valtasuhteiden esiin kirjoittamiseen ja jokaisen tutkijan toimijuuden tulkitsemiseen valtasuhteissa rakentuvaksi. (Sinfield 
2007, viii, 80-81.) Tästä ymmärtääkseni on kyse siinäkin, kun Kristina Malmio samastaa ongelmallisen kapeasti poliittisuuden vaaleissa äänestämiseen ja tulkitsee ainoastaan amerikkalaiskampuksilla esiintyvän tarpeita turvata akateemisen toimintaympäristön moniarvoisuus, oikeudenmukaisuus ja tasa-arvoisuus (Hekanaho 2007, 76; Malmio 2007, 86-87). Oman käsitykseni ja kokemukseni mukaan tämä keskustelu koskettaa yhtä lailla suomalaista yliopistoa, jolloin tuntemani ja seuraamani angloamerikkalaisena alkaneen kiistan esitteleminen ja taustoittaminen lienee hyödyllistä myös kotimaisessa kontekstissa. Emme täällä toimi sen kummemmin lintukodossa kuin esimerkiksi itselleni tärkeät yhdysvaltalaiset kollegat, jotka tekevät tutkimus- ja opetustyötään huomattavan moni-ilmeisen English-oppiaineen sisällä. Sen suhteen en ole kotikontekstissanikaan puolueeton, tuleeko yliopistojen taata opiskelijoilleen ja työntekijöilleen oikeudenmukainen, tasa-arvoinen ja keskinäisiä erojamme kunnioittava toimintaympäristö ja tuleeko esimerkiksi opettajuutemme tukea tätä.

Kirjoittaessani tutkimuksesta, sen avoimuudesta, moniarvoisuudesta, läpinäkyvyydestä sekä tutkijan kyvystä ja valmiudesta reflektoida omaa tutkija- ja kirjoittajapositiotaan kirjoitin - mistäpä muusta kuin juuri poliittisuudesta. Foucault'ta seuraillen esitän, että tutkija/lukija tuo väistämättä mukanaan jokaiseen lukemisaktiin ne vallan verkostot, jotka häntä lukevana, kysyvänä ja tutkivana subjektina tuottavat. Siksi jokainen kohtaamisemme tekstien kanssa on yhdeltä ulottuvuudeltaan poliittinen. Laajassa merkityksessään poliittista lukijuutta voisi kuvata esimerkiksi käsitteellä valtasensitiivinen tutkimusote (Hekanaho 2007, 78). Feministisen, postkoloniaalisen ja queertutkimuksen tavoin monissa tutkimussuuntauksissa tutkijan oman position reflektio kirjoitetaan yleensä näkyviin. Se ei silti merkitse, että vain nämä tutkimussuuntaukset olisivat tarkoittamassani mielessä poliittisia tai että niiden tekijät tulkitsisivat tutkimuksen karkeasti politiikan tekemisen välineeksi. Sen sijaan kyky ja valmius analysoida omaa tutkijapositiota kuuluvat aina hyvän tutkijan valmiuksiin: lukijoina tuomme aina mukanamme oman lukijuutemme tuottavat vallan ja kielen yhteen kietoutumat. Tässä mielessä muuttujat kuten sukupuoli, luokka, seksuaalisuus jne. joka tapauksessa kirjoittautuvat kaikkiin kohtaamisiimme esimerkiksi tekstien kanssa.

Merkityksellistä on näiden muuttujien analysoiminen ja reflektoiminen osana omaa toimijuutta; tässä mielessä kaikki lukeminen on vääjäämättä poliittista, ei siinä merkityksessä, että kirjallisuudentutkimus olisi tehokkain tapa tuottaa konkreettisia muutoksia yhteiskuntaan! Sen sijaan en ole missään esittänyt, että kaikki toimintamme olisi redusoitavissa politiikan tekemiseen. Politiikasta, erityisesti sen reaktionaarisessa muodossa, kirjoitin esitellessäni Daphne Patain ja Will H. Corralin toimittaman, avoimesti yliopistopoliittisen Theory's Empire -antologian (2005) taustaa ja kontekstia. Omaan poliittisuuden ymmärrykseeni liittyy tietty kirjoittamisen integriteetin vaatimus: tottahan tekstejä voi lukea vastakarvaan ja kuin piru raamattua, mutta olennaista 
on kommunikoida tämä valinta ja sen konteksti lukijalle. Jos lukee nimenomaan yliopistopoliittiseksi, useita tutkimussuuntauksia vastustavaksi "toisinajattelun kokoelmaksi" toimitettua teosta, on minusta paikallaan tuoda tämä tosiseikka esiin silloinkin, kun ryhtyy tarkastelemaan teosta jostakin muusta näkökulmasta. Tämä on nähdäkseni yksi osa tutkijan jatkuvan oman toiminnan reflektoimisen vaatimusta. Kristina Malmion tavoin en lukenut "Hekanahon" tekstiin tosikkomaista kiihkoilua, vaan luin sen nimenomaan piruilevana asettumisena "kampusten epäpoliittisen vapauden" puolustajien diskurssiin. Kyse lienee pikemminkin ivasta kuin vallankumousromantiikasta.

\section{Pia Livia Hekanaho}

\section{Lähteet}

HAAPALA VESA JA RIIKKA ROSSI 2007: Hajamietteitä vaaliviikkojen jälkeen. Avain 2, 2-4.

HEKANAHO, PIA LIVIA 2007: Teorian vastaisku: pitääkö humanistin äänestää republikaaneja? Avain 1, 76-79.

MALMIO, KRISTINA 2007: Voiko suomalainen kirjallisuudentutkija äänestää USA:n vaaleissa? Avain 2, 86-88.

SINFIELD, ALAN 2007: Cultural Politics - Queer Reading. 2. ed. London: Routledge. Theory's Empire. An Anthology of Dissent 2005. Toim. Daphne Patai ja Will H. Corral. New York: Columbia University Press. 